Original scientific paper

\title{
ECONOMIC EFFECTIVENESS OF MECHANIZED HARVESTING OF CHAMOMILE ${ }^{1}$
}

\author{
Sanjin Ivanovič ${ }^{2}$, Miloš Pajič́c ${ }^{3}$ Todor Markovićc ${ }^{4}$
}

\begin{abstract}
Summary
Chamomile as a medicinal and aromatic plant is very important as a valuable product in the world market of medicinal plants. Regardless of that, there have been only a few researches so far concerning economic effects of its production. Costs of chamomile harvesting require special attention as these costs, as a rule, account for a major portion in the structure of total costs.

The aim of this paper is to show when it is economically justified to substitute hand harvesting by machine harvesting as well as to determine the largest possible investment in purchasing different harvesters for chamomile harvesting. For that purpose were used enterprise budgeting (analytical calculations) of chamomile production, calculations of costs of agricultural machinery, as well as dynamic methods for investment evaluation (present value method).

It was determined that it is economically justified to substitute hand harvesting with mechanized harvesting of chamomile on land area of over 2.5, i.e. 4 ha of chamomile, depending on the harvester type. If harvesters are used on land areas smaller than this economical effectiveness of the investments in purchasing them, i.e. their present value, depends on the harvester type and the land area on which chamomile is grown.
\end{abstract}

Key words: chamomile, harvesting costs, hand harvesting, harvester, present value.

JEL: $Q 12$

1 This paper is a result of the research on the project No. 179028 named: „Rural Labor Market and Rural Economy of Serbia - Income Diversification as a Tool to Overcome Rural Poverty“, and project TR-31051 named "Improvement of biotechnological procedures as a function of rational utilization of energy, agricultural products productivity and quality increase". Projects are financed by the Ministry of Education, Science and Technological Development of the Republic of Serbia.

2 Sanjin Ivanović, Ph.D., Associate Professor, University of Belgrade, Faculty of Agriculture, Department of Agricultural Economics, Nemanjina 6, 11080 Zemun, Belgrade, Republic of Serbia, Phone: +381 (11) 2615 315, ext: 426, E-mail: sanjinivanovic@agrif.bg.ac.rs

3 Miloš Pajić, Ph.D., Assistant Professor, University of Belgrade, Faculty of Agriculture, Institute of Agricultural Engineering, Nemanjina 6, 11080 Zemun, Belgrade, Republic of Serbia, Phone: +381 (11) 2615 315, ext: 442, E-mail: paja@agrif.bg.ac.rs

4 Todor Marković, Ph.D., Assistant Professor, University of Novi Sad, Faculty of Agriculture, Department of Agricultural Economics and Rural Sociology, Trg Dositeja Obradovića 8, 21000 Novi Sad, Republic of Serbia, Phone: +381 (21) 4853 419, E-mail: todor@polj.uns.ac.rs

EP 2014 (61) 2 (319-330) 


\section{Introduction}

Chamomile is a medicinal plant of particular importance and wide use in different industries. Growing medicinal herbs can be an opportunity for farms to diversify the structure of their production, thus decreasing the risk of farming which exists when the usual cultures in sowing structure are grown. Apart from that, high profit per unit of land area is achieved in chamomile production, which enables farmers to significantly increase the total result of farm business.

On the other hand, medicinal plants have no share in the sowing structure of majority of the farms. The reasons for this are multiple, but the main ones are unregulated market, export issues etc. Apart from that, production of medicinal herbs requires specific knowledge from the field of production technology, and sometimes use of special machines and equipment. This is why it is so difficult for farmers to decide to start this production. Small participation of chamomile in the sowing structure of farms is the reason why economic effects of its growing have not been studied enough. On the other hand, because of Serbia's accession to the European Union it is possible to expect harmonization of the national with EU regulations and standards (Antevski et al., 2012), which will make it easier for Serbian agricultural products to appear in the European Union market. Based on that, some current issues regarding selling of chamomile could be solved.

One of the most important issues in chamomile production is mechanization of harvesting. The best quality of chamomile is obtained when it is harvested by hand, which is labourintensive, causes high price of the product, it is difficult to organize harvesting process and it causes a series of other problems (Franke, Schilcher, 2005). Mechanized harvesting requires a forced compromise between the quality of harvesting and the degree of mechanization, just like with other cultures. There are a large number of harvesters for chamomile harvesting in the market, self-propelled, pull-type, semi-mounted and tractor mounted harvesters. They all differ according to their technical properties and construction, as well as the quality of harvesting and performance (Pajić, 2012). Considering specifics of using different types of harvesters for chamomile harvesting in the Republic of Serbia, researches so far performed have shown that semi-mounted and tractor mounted harvesters offer better economic effects (Pajić et al., 2011).

Taking into account the problem of chamomile production, Singh et al. (2011) state that chamomile harvesting requires significant employment of labour, which is the reason for having the greatest share in chamomile production costs. Santucci et al. (2013) analysed profitability of chamomile production, starting from the assumption that chamomile is harvested only by hand, which was considered to be justified in this research because they analysed the situation in which unemployment in rural areas was very high, while the labour costs were low.

Hand harvesting of chamomile in Serbia is typical for small farms and undeveloped or underdeveloped regions, while large chamomile producers choose only mechanized harvesting. In addition, harvesters which are used for chamomile harvesting have different technical characteristics and different operation qualities (Pajić et al., 2001). 
Because of this, different harvesters influence different revenues, costs and profit in chamomile production. The choice of harvester for chamomile harvesting can be made based on different methods, and one of the methods is calculating current value of costs of these machines (Ivanović et al., 2007). In order to determine the current value of costs, the authors used different discount rates. They also established the limitary discount rate at which costs of competitive machines are equal. Stričík and Salamon (2007) studied the problem of investing in harvester for chamomile harvesting, as well as the optimum size of land for chamomile growing.

The aim of this paper is to determine whether it is more profitable for a farm to harvest chamomile by hand or by using mechanization, i.e. what is the limitary land area under chamomile for economically justified switching to mechanized chamomile harvesting from hand harvesting. Another aim of the paper was to evaluate which of the harvesters for chamomile harvesting (available in the market) is more economically acceptable. In order to do that, profit in chamomile production achieved on different land areas under chamomile will be calculated, bearing in mind different harvesting methods (hand harvesting, mechanized harvesting). The aim was also to calculate the present value of investments in specific types of harvesters.

\section{Materials and methods}

This research was based on the data obtained through experiments in production conditions. The researches were carried out in the research and production fields of the Institute of Medicinal Plant Research "Dr Josif Pančić" in Pančevo, during the production year 2006/2007. Field researches were carried out by split-plot method, in three repetitions, on the total land area of $7,200 \mathrm{~m}^{2}$. During the experiment parameters of operation and performances of hand harvesting and harvesting of two types of harvesters were followed (harvester $\mathrm{A}$ tractor mounted harvester, harvester B - semi-mounted harvester).

Harvester A was tractor mounted harvester "NB 2004", powered by tractor "IMT 560". Harvester working width was $2 \mathrm{~m}$. This harvester had no container for the harvested chamomile, but operates with a tractor trailer. The tractor trailer was used for collecting of the harvested chamomile and it was replaced by another after filling up. This production system required at least two tractors, a mounted harvester and two tractor trailers in order to perform the entire process of harvesting without a significant delay.

Harvester B was a semi-mounted harvester "VB 2002", powered by tractor "MTZ 82.1". It had a container for the harvested chamomile $\left(2.2 \mathrm{~m}^{3}\right)$. Working width of this harvester was $2 \mathrm{~m}$. This harvester, from the perspective of tractor machinery, required: two tractors, semi-mounted harvester and one tractor trailer in order not to cause a significant delay in chamomile harvesting.

Analysis started from the assumption that chamomile is produced to be sold as dried flowers. Apart from this type of production, chamomile can be produced in order to obtain ether oil. There is also a combined type of production, in which a part of the product is used as dried flowers, while the rest is used for producing ether oil (Falzari, Menary, 2003). The 
analysis of production of dried flowers has been chosen based on the fact that this type of production has the best economic effects (Pajić, 2012).

Quality of the harvested chamomile is defined by 4 quality categories, according to the standards recommended by the Institute for standardization of Serbia (2012). In order to determine profit in chamomile production, the appropriate analytical calculations (enterprise budgeting) were used, as well as calculations of costs of agricultural machinery according to the methodology suggested by Gogić (2009). Apart from that, for analysis were used data on the price of operation of agricultural machinery published by the Cooperative union of Vojvodina (2011).

The method of present value of investment was also used, which enabled calculation of the highest amount that can be invested in purchasing chamomile harvester. This method was used to evaluate whether investment in purchasing different harvesters is economically justified.

\section{Results and discussion}

The basis for further analyses was calculation of costs of chamomile production (Table 1). These costs are always the same, regardless of how the chamomile is harvested (by hand or with mechanization), and for what purpose it is used later (for obtaining dried flowers or production of ether oil). This calculation comprises only of costs, without revenues, as the revenues depend on a larger number of factors such as the use of chamomile, structure of yield according to quality classes etc.

Table 1. Costs of chamomile production (1 ha)

\begin{tabular}{|l|c|c|r|r|}
\hline \multicolumn{1}{|c|}{ Type of cost } & Unit & Quantity & $\begin{array}{c}\text { Price per unit } \\
\text { (EUR) }\end{array}$ & \multicolumn{1}{c|}{$\begin{array}{c}\text { Amount } \\
\text { (EUR) }\end{array}$} \\
\hline I Seed & $\mathrm{kg}$ & 2.00 & 50.00 & 100.00 \\
\hline II Irrigation & ha & 1.00 & 120.00 & 120.00 \\
\hline III Machinery costs (1 - 5) & \multicolumn{5}{|c|}{} & \multicolumn{3}{|c|}{} \\
\hline 1. Ploughing of stubble field & ha & 1.00 & 40.00 & 40.00 \\
\hline 2. Deep ploughing & ha & 1.00 & 80.00 & 80.00 \\
\hline 3. Seedbed preparation & ha & 1.00 & 20.00 & 20.00 \\
\hline 4. Sowing & ha & 1.00 & 20.00 & 20.00 \\
\hline 5. Rolling & ha & 1.00 & 10.00 & 10.00 \\
\hline IV Total costs of production (I + II + III) & \multicolumn{5}{|l|}{} \\
\hline
\end{tabular}

Source: According to authors' calculation.

This calculation also lacks the costs for mineral fertilizers and plant protection means, which is in accordance with the intended use of chamomile as medicinal plant or in cosmetic industry. Accordingly, this calculation is focused on organic and integrated production of chamomile, in accordance with the export requirements of the EU countries. It should also be underlined that in this calculation labour costs were not separately listed, but that they are included into the agricultural machinery costs. 
The value of chamomile production was determined for three different cases - when chamomile is hand harvested, or when harvesters A and B are used for harvesting (Table 2). In all three cases different technological yield was obtained, as well as different percentage of specific chamomile classes in the total yield. In all three cases prices of chamomile were determined under the assumption that after harvesting it would be used as dried flowers.

Table 2. Value of chamomile production for different harvesting methods

\begin{tabular}{|c|c|c|c|c|}
\hline & Indicators & Harvester A & Harvester B & $\begin{array}{c}\text { Hand } \\
\text { harvesting }\end{array}$ \\
\hline & $\begin{array}{l}\text { Technological yield, dried, } \\
12 \% \text { humidity (kg/ha) }\end{array}$ & 893.00 & 881.00 & 932.00 \\
\hline & Participation (\%) & 45.84 & 39.81 & 64.30 \\
\hline $\mathrm{Cl}_{\mathrm{acs}} \mathrm{f}$ & Quantity (kg) & 409.35 & 350.73 & 599.28 \\
\hline Class I & Price (EUR/kg) & 4.00 & 4.00 & 4.00 \\
\hline & Value of production(EUR/ha) & $1,637.40$ & $1,402.90$ & 2.397 .10 \\
\hline & Participation (\%) & 24.10 & 24.89 & 20.72 \\
\hline $\mathrm{Cl}$ acs? & Quantity (kg) & 215.21 & 219.28 & 193.11 \\
\hline Crass 2 & Price (EUR/kg) & 2.50 & 2.50 & 2.50 \\
\hline & Value of production (EUR/ha) & 538.03 & 548.20 & 482.78 \\
\hline & Participation (\%) & 26.55 & 31.12 & 11.10 \\
\hline Clacs 3 & Quantity (kg) & 237.09 & 274.17 & 103.45 \\
\hline Class 3 & Price $(\mathrm{EUR} / \mathrm{kg})$ & 1.50 & 1.50 & 1.50 \\
\hline & Value of production (EUR/ha) & 355.64 & 411.25 & 155.18 \\
\hline & Participation (\%) & 3.51 & 4.18 & 3.88 \\
\hline & Quantity (kg) & 31.34 & 36.83 & 36.16 \\
\hline Class 4 & Price $(\mathrm{EUR} / \mathrm{kg})$ & 0.50 & 0.50 & 0.50 \\
\hline & Value of production (EUR/ha) & 15.67 & 18.41 & 18.08 \\
\hline Total va & lue of production (EUR/ha) & $2,546.75$ & $2,380.77$ & $3,053.14$ \\
\hline
\end{tabular}

Source: According to authors' calculation.

In order to calculate the profit of chamomile production, all the costs occurring must be taken into account, not just those arising from its production, but also those arising in the course of harvesting, transport, drying, processing and packing. These phases cannot be separated from the production process because chamomile is sold as dried flowers, i.e. its market value is defined only when the processes of drying, processing and packing are finished.

In practice, chamomile is mainly hand harvested on small holdings, while on the large land areas the appropriate harvesters are used. There are two important reasons for switching from hand harvesting to mechanized chamomile harvesting. The first reason is the problem of providing and organizing sufficient number of workers in order to enable chamomile harvesting in optimal agro technical period of 7 to 12 days. The other reason is relatively low investment into harvesters $(6,000-7,000$ EUR), so that they can be purchased by means of bank loan or combination of equity and bank loan. One should bear in mind here all the limitations related to the loans for agricultural producers (Jolović et al., 2014). 
In order to determine the profit in chamomile production, the calculations were formulated for hand harvesting (Table 3.), harvester A (Table 4.), and harvester B (Table 5). The calculations took into account different land areas for chamomile harvesting.

Table 3. Profit in chamomile production when hand harvested (EUR/ha)

\begin{tabular}{|l|r|r|r|}
\hline \multicolumn{1}{|c|}{ Indicators } & \multicolumn{1}{c|}{$\mathbf{1}$ ha } & \multicolumn{1}{c|}{$\mathbf{5}$ ha } & \multicolumn{1}{c|}{$\mathbf{1 0}$ ha } \\
\hline I Value of production (revenue) & $3,053.14$ & $15,265.69$ & $30,531.39$ \\
\hline II Costs (1 to 6) & $2,154.00$ & $10,770.00$ & $21,540.00$ \\
\hline 1. Production costs & 390.00 & $1,950.00$ & $3,900.00$ \\
\hline 2. Machinery costs (during harvesting) & 0.00 & 0.00 & 0.00 \\
\hline 3. Labour costs (during harvesting) & $1,134.00$ & $5,670.00$ & $11,340.00$ \\
\hline 4. Transportation costs & 10.00 & 50.00 & 100.00 \\
\hline 5. Costs of drying & 450.00 & $2,250.00$ & $4,500.00$ \\
\hline 6. Costs of processing and packing & 170.00 & 850.00 & $1,700.00$ \\
\hline Profit (I - II) & $\mathbf{8 9 9 . 1 4}$ & $\mathbf{4 , 4 9 5 . 6 9}$ & $\mathbf{8 , 9 9 1 . 3 9}$ \\
\hline
\end{tabular}

Source: According to authors' calculation.

Table 4. Profit in chamomile production when harvester $\mathrm{A}$ is used (EUR/ha)

\begin{tabular}{|l|r|r|r|}
\hline \multicolumn{1}{|c|}{ Indicators } & \multicolumn{1}{c|}{$\mathbf{1}$ ha } & \multicolumn{1}{c|}{$\mathbf{5}$ ha } & \multicolumn{1}{c|}{$\mathbf{1 0}$ ha } \\
\hline I Value of production (revenue) & $2,546.75$ & $12,733.73$ & $25,467.47$ \\
\hline II Costs (1 to 6) & $2,371.28$ & $6,926.42$ & $12,620.33$ \\
\hline 1. Production costs & 390.00 & $1,950.00$ & $3,900.00$ \\
\hline 2. Machinery costs (during harvesting) & $1,325.23$ & $1,696.15$ & $2,159.81$ \\
\hline 3. Labour costs (during harvesting) & 21.05 & 105.26 & 210.53 \\
\hline 4. Transportation costs & 15.00 & 75.00 & 150.00 \\
\hline 5. Costs of drying & 450.00 & $2,250.00$ & $4,500.00$ \\
\hline 6. Costs of processing and packing & 170.00 & 850.00 & $1,700.00$ \\
\hline Profit (I - II) & $\mathbf{1 7 5 . 4 6}$ & $\mathbf{5 , 8 0 7 . 3 2}$ & $\mathbf{1 2 , 8 4 7 . 1 4}$ \\
\hline
\end{tabular}

Source: According to authors' calculation.

Table 5. Profit in chamomile production when harvester B is used (EUR/ha)

\begin{tabular}{|l|r|r|r|}
\hline \multicolumn{1}{|c|}{ Indicators } & \multicolumn{1}{c|}{$\mathbf{1}$ ha } & \multicolumn{1}{c|}{$\mathbf{5 ~ h a}$} & \multicolumn{1}{c|}{$\mathbf{1 0}$ ha } \\
\hline I Value of production (revenue) & $2,380.77$ & $11,903.85$ & $23,807.70$ \\
\hline II Costs (1 to 6) & $2,375.57$ & $7,009.86$ & $12,802.73$ \\
\hline 1. Production costs & 390.00 & $1,950.00$ & $3,900.00$ \\
\hline 2. Machinery costs (during harvesting) & $1,345.05$ & $1,857.23$ & $2,497.46$ \\
\hline 3. Labour costs (during harvesting) & 10.53 & 52.63 & 105.26 \\
\hline 4. Transportation costs & 10.00 & 50.00 & 100.00 \\
\hline 5. Costs of drying & 450.00 & $2,250.00$ & $4,500.00$ \\
\hline 6. Costs of processing and packing & 170.00 & 850.00 & $1,700.00$ \\
\hline Profit (I - II) & $\mathbf{5 . 2 0}$ & $\mathbf{4 , 8 9 3 . 9 9}$ & $\mathbf{1 1 , 0 0 4 . 9 8}$ \\
\hline
\end{tabular}

Source: According to authors' calculation. 
The obtained results show that in all the observed cases there is profit in chamomile production. Comparing hand and mechanized harvesting, it is noticeable that profit is higher on small production areas in case of hand harvesting in comparison to mechanized harvesting. Higher profit in case of hand harvesting occurs for two reasons. The first reason is much higher percentage of the first class chamomile from hand harvesting than from mechanized harvesting. The other reasons are high fixed costs of the harvesters used for chamomile harvesting, which significantly increase the costs of chamomile production on small production areas. However, the total profit achieved is increased in this production with the increase of the area under chamomile, and higher profit is achieved by mechanized harvesting as average fixed costs are decreased (Graph 1).

Graph 1. Distribution of profit in chamomile production on different land areas

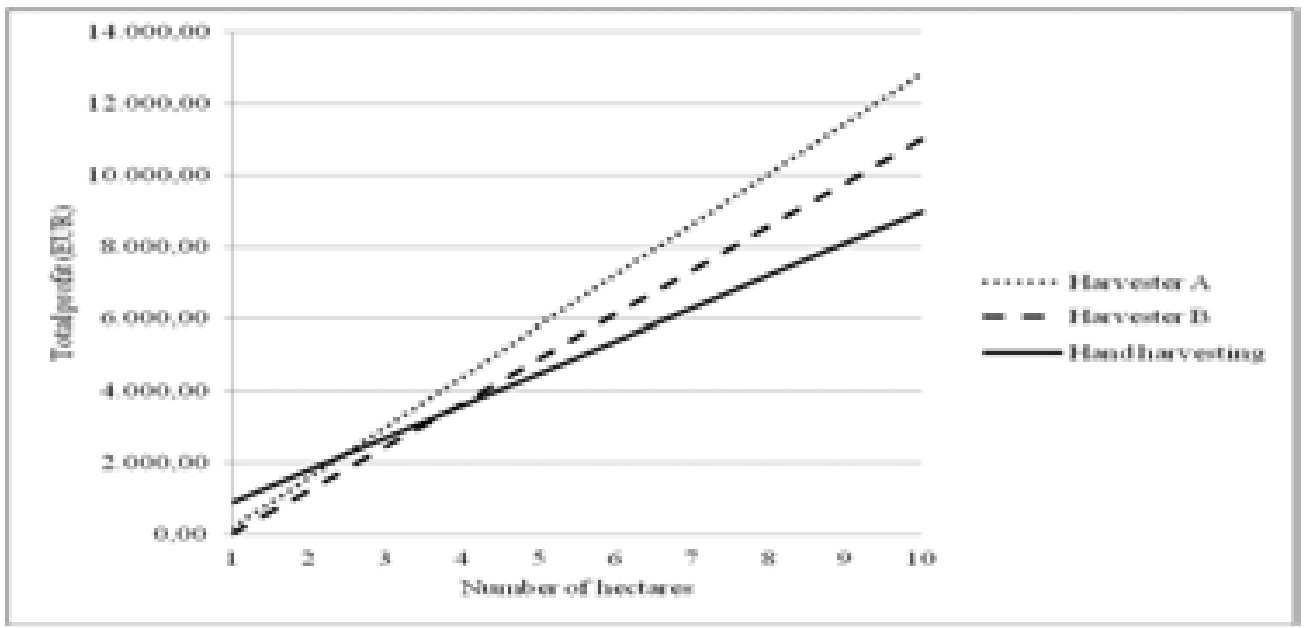

Source: According to authors' calculation.

Hand harvesting of chamomile is the most convenient on up to 2.5 ha land area because it provides the highest total profit. However, after that land area the first choice in economic terms is harvester A. As far as the harvester B is concerned, it gives worse economic results than harvester A. Nevertheless, if a farm would choose to buy harvester B, this harvester as the replacement for hand harvesting would have been profitable only if four or more hectares of chamomile were grown.

Apart from that, another problem is whether it is more profitable for a farm to buy harvester A or harvester B for harvesting chamomile on larger plots. Graph 2 shows that purchasing of harvester $\mathrm{A}$ is more profitable for farms because it provides higher total profit on all analysed production areas. Moreover, with the increase of the land area under chamomile, the advantages of harvester A rise compared to the harvester B as far as the total profit is concerned. 
Graph 2. Comparing total profit for harvesters A and B for different land areas

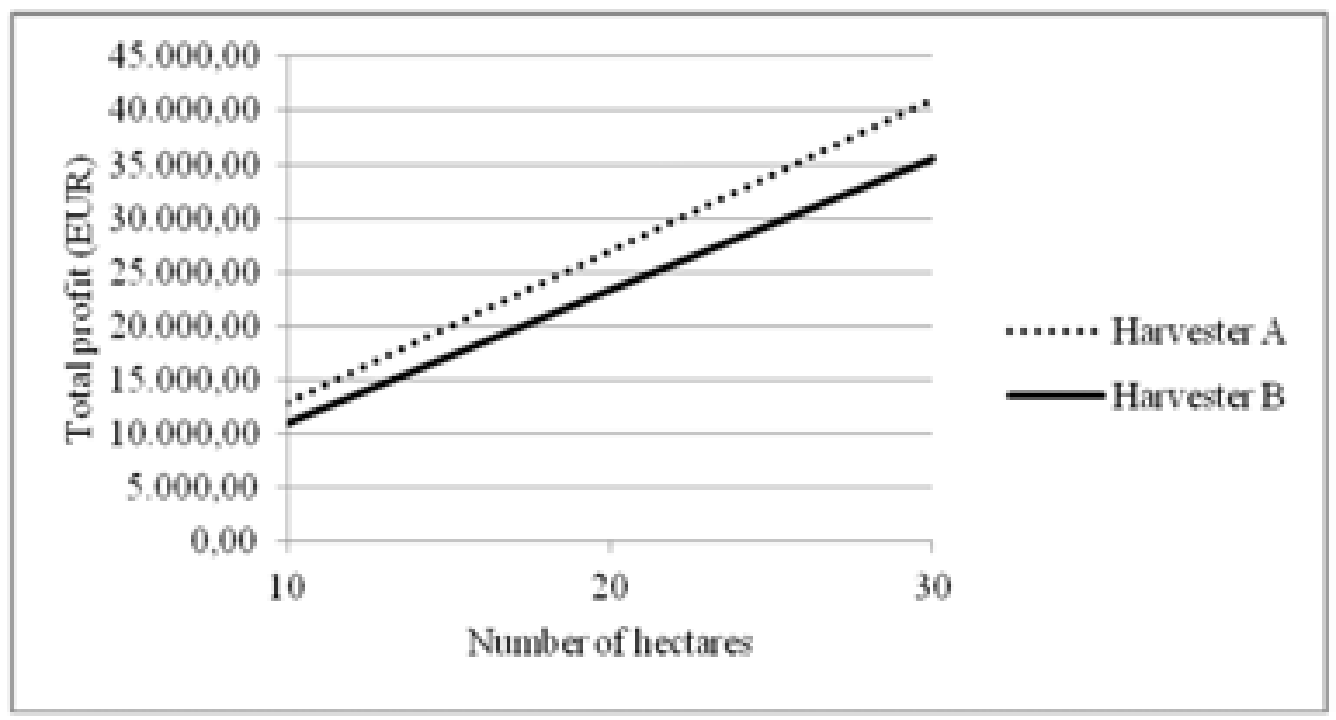

Source: According to authors' calculation.

Likewise, if profit per hectare is observed (Graph 3), it is possible to see that profit is higher when harvester A is used. The profit per hectare of chamomile rises with the number of hectares, but the increase is reduced gradually.

Although effects per working hour of harvester A and B are technically identical (harvesting of 1 ha of chamomile takes them 5.60 working hours), there are several reasons for which harvester $\mathrm{A}$ is economically more acceptable:

- The first reason is that harvester B has higher price in the market, and thus higher fixed costs (depreciation costs, interest etc.). Harvester B is more expensive because it has its own container for the harvested chamomile and the appropriate hydraulic system for that container.

- The second reason is that harvester B requires tractor of higher power, and thereby has higher variable costs.

- Apart from that, harvester A gives somewhat higher content of the first class harvested chamomile flowers than harvester B.

- On the other hand, harvester A demands somewhat more labour consumption during harvesting, as well as an additional trailer, but these costs still have no significant influence on the profit of chamomile production. 
Graph 3. Comparing profit for harvesters A and B for different land areas

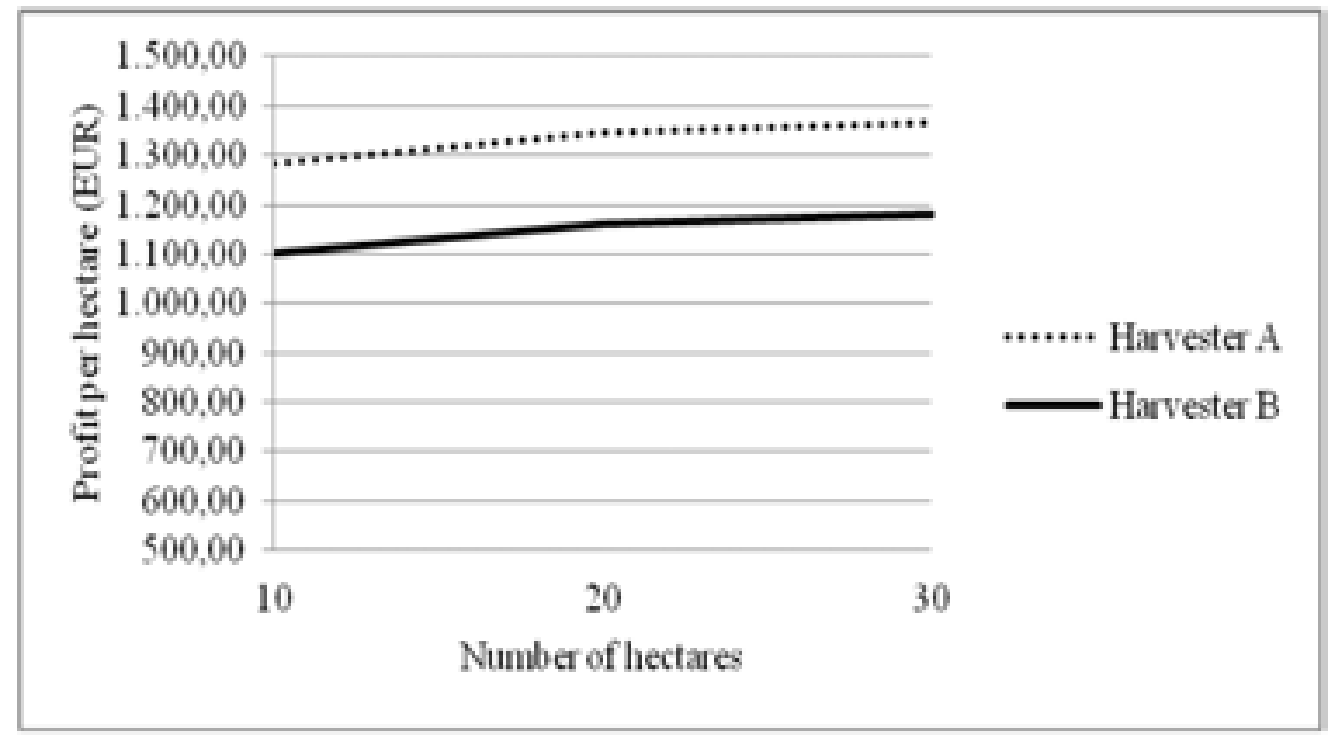

Source: According to authors' calculation.

If chamomile producers chose to purchase harvester for chamomile harvesting on small lad areas (in order to avoid possible organizational issues of labour force), the question is how much they could pay for these harvester at most. That is, what is the present value of the analysed harvesters if they are used on different land areas under chamomile. Table 6 shows present value of harvester A for land areas under chamomile on which it is most acceptable to use hand harvesting (for 1 ha and 2 ha). Table 7 shows present value of harvester $B$ if it is used on land areas on which it is more economically justified to use hand harvesting (land areas from 1 to 3 hectares). The calculation started from the assumption that all cash inflows and outflows arise at the end of the year, that discount rate is $8 \%$, and that maximum period of harvesters' utilization is 10 years. Salvage value of the observed harvesters is neglected.

Table 6. Present value of harvester A on different land areas on which it is used

\begin{tabular}{|l|r|r|}
\hline \multicolumn{1}{|c|}{ Indicators } & \multicolumn{1}{c|}{$\mathbf{1}$ ha } & \multicolumn{1}{c|}{$\mathbf{2}$ ha } \\
\hline Average annual cash inflow (EUR) & $2,546.75$ & $5,093.49$ \\
\hline Average annual cash outflow (EUR) & $1,435.28$ & $2,574.07$ \\
\hline Net cash flow (EUR) & $1,111.46$ & $2,519.43$ \\
\hline Discount rate (10 years, 8\%) & 6.7101 & 6.7101 \\
\hline Present value (EUR) & $\mathbf{7 , 4 5 8 . 0 3}$ & $\mathbf{1 6 , 9 0 5 . 6 1}$ \\
\hline Investment in harvester (EUR) & $\mathbf{6 , 5 0 0 . 0 0}$ & $\mathbf{6 , 5 0 0 . 0 0}$ \\
\hline
\end{tabular}

Source: According to authors' calculation. 
Table 7. Present value of harvester B on different land areas on which it is used

\begin{tabular}{|l|r|r|r|}
\hline \multicolumn{1}{|c|}{ Indicators } & \multicolumn{1}{c|}{$\mathbf{1}$ ha } & \multicolumn{1}{c|}{$\mathbf{2}$ ha } & \multicolumn{1}{c|}{$\mathbf{3}$ ha } \\
\hline Average annual cash inflow (EUR) & $2,380.77$ & $4,761.54$ & $7,142.31$ \\
\hline Average annual cash outflow (EUR) & $1,367.57$ & $2,526.15$ & $3,684.72$ \\
\hline Net cash flow (EUR) & $1,013.20$ & $2,235.40$ & $3,457.59$ \\
\hline Discount rate (10 years, 8\%) & 6.7101 & 6.7101 & 6.7101 \\
\hline Present value (EUR) & $\mathbf{6 , 7 9 8 . 6 6}$ & $\mathbf{1 4 , 9 9 9 . 7 3}$ & $\mathbf{2 3 , 2 0 0 . 8 0}$ \\
\hline Investment in harvester (EUR) & $\mathbf{7 , 0 0 0 . 0 0}$ & $\mathbf{7 , 0 0 0 . 0 0}$ & $\mathbf{7 , 0 0 0 . 0 0}$ \\
\hline
\end{tabular}

Source: According to authors' calculation.

It is possible to see that purchasing harvester A under the given conditions would be economically justified event if it was bought only for 1 ha under chamomile as its present value would be higher than the investment of purchasing it. Although purchasing harvester A would have been economically justified even for this small land area, hand harvesting would have provided higher total profit.

On the other hand, investment in purchasing harvester B would not have been economically justified if it was used only on 1 ha area under chamomile because its market value is 7,000 EUR, while it is possible to invest in purchasing it 6,798.66 EUR at most. If harvester B was used on 2 or 3 ha area, investment in purchasing it would have been economically justified. However, one should bear in mind that hand harvesting on these plots provides higher total profit.

\section{Conclusion}

Determination of profit in chamomile production is a complex process which should take into accounts not only costs of chamomile production, but also the costs of harvesting, transport, drying, packing etc. Moreover, the profit largely depends on harvesting method, since hand harvesting and mechanized harvesting generate different costs, but also different revenues.

The analysis showed that it is economically justified to switch from hand harvesting to mechanized harvesting on land areas bigger than 2.5 ha (in case of harvester A), or 4 ha (in case of harvester B). Analysis of the present value showed that investment in purchasing harvester $\mathrm{A}$ is economically justified even on land area of 1 ha, which is not the case with the investment in harvester B. The economic advantage of the harvester $\mathrm{A}$ relative to the harvester $B$ increases even more with the size of the land area on which the harvesters are used.

\section{Literature}

1. Antevski, M., Petrović, P., Vesić, D. (2012): Development Perspectives in Agriculture and Rural Areas in Serbia in the EU Integration Process, Economics of Agriculture, Vol. 59, No. 2, pp. 243 - 251, The Balkan Scientific Association of Agrarian Economists, Belgrade, Serbia. 
2. Falzari, L. M., Menary, R. C. (2003): Chamomile for oil and dried flowers, Project No UT-28A, Barton, A.C.T., RIRDC, Australia.

3. Franke, R., Schilcher, H. (2005): Chamomile Industrial profiles, Taylor and Francis, London, United Kingdom.

4. Gogić, P.(2009): Teorija troškova sa kalkulacijama (u proizvodnji i preradi poljoprivrednih proizvoda), Poljoprivredni fakultet, Beograd - Zemun, Srbija.

5. Ivanović, S., Pajić, M., Ivanović, L. (2007): Choosing Type Of Chamomile Harvester Based On Current Value Of Usage Costs, Proceedings from the conference - I International Symposium on Chamomile Research, Development and Production, Presov, Slovak Republic, ISHS Acta Horticulturae, 749, pp. 259-264.

6. Standard SRB.E.B3.015:1963., Službeni glasnik 13/65, 1ED, Institut za standardizaciju Srbije, 2012, Beograd, Srbija.

7. Jolović, A., Njegovan, Z., Čavlin, M. (2014): Financing of the Agriculture in Serbia: State and Prospects, Economics of Agriculture, Vol. 61, No. 1, pp. 127 - 137, The Balkan Scientific Association of Agrarian Economists, Belgrade, Serbia.

8. Pajić, M. (2012): Optimizacija mehanizovanog procesa ubiranja kamilice (Matricaria chamomilla L.), Doktorska disertacija, Poljoprivredni fakultet, Univerzitet u Beogradu, Beograd - Zemun, Srbija.

9. Pajić, M., Ivanović, S., Oljača, M., Pajić, V., Radojević, R., Ružičić, L. (2011): Uticaj različitih tipova kombajna za ubiranje kamilice na kvalitet $i$ visinu dobiti u proizvodnji kamilice, Poljoprivredna tehnika, Vol. XXXVI, No. 2, pp. 43 - 51, Institut za poljoprivrednu tehniku, Poljoprivredni fakultet, Univerzitet u Beogradu, Beograd - Zemun, Srbija.

10. Pajić, M., Radojević, R., Raičević, D. (2001): Nova tehnološka rešenja ubiranja i sušenja kamilice na malom posedu, Poljoprivredna tehnika, Vol. XXIV, No. 1/2, pp. 43-52, Institut za poljoprivrednu tehniku, Poljoprivredni fakultet, Univerzitet u Beogradu, Beograd Zemun, Srbija.

11. Santucci, F. M., Cardone, L., Mostafa, M. S. M. (2013): Labor Requirements and Profitability of Chamomile (Matricaria Chamomilla l.) in Egypt, ARPN Journal of Agricultural and Biological Science, vol. 8(5), pp. 373-379, Asian Research Publishing Network (ARPN), available at: www.arpnjournals.com/jabs/research papers/rp 2013/jabs 0513 564.pdf

12. Singh, O., Khanam, Z., Misra, N., Srivastava, M. K. (2011): Chamomile (Matricaria chamomilla L.): An overview, Pharmacognosy Rev., Vol. 5, No. 9, pp. 82-95, Medknow Publications And Media Pvt. Ltd., part of Wolters Kluwer Health, Mumbai, India, available at: www.ncbi.nlm.nih.gov/pmc/articles/PMC3210003/

13. Stričík, M., Salamon, I. (2007): Investment Rating With A Combine Harvester Acquisition For Chamomile Flower Picking, Proceedings from the conference - I International Symposium on Chamomile Research, Development and Production, Presov, Slovak Republic, ISHS Acta Horticulturae, 749, pp. 265-268.

14. Cenovnik mašinskih usluga u poljoprivredi, Zadružni savez Vojvodine, 2011, Novi Sad, Srbija.

EP 2014 (61) 2 (319-330) 


\section{EKONOMSKA EFEKTIVNOST MEHANIZOVNOG UBIRANJA KAMILICE}

\section{Sanjin Ivanovič́, Miloš Pajićc ${ }^{6}$, Todor Markovićc}

\section{Rezime}

Kamilica kao lekovita i aromatična vrsta je od velikog značaja, jer predstavlja značajan artikal na svetskom tržištu lekovitog bilja. Bez obzira na to, do sada postoji samo mali broj istraživanja koja se odnose na ekonomske efekte njene proizvodnje. Posebnu pažnju kod gajenja kamilice treba obratiti na troškove ubiranja, koji po pravilu imaju najveće učešce u strukturi ukupnih troškova.

Cilj ovog rada je da utvrdi kada je ekonomski opravdano preći sa ručnog na mašinsko ubiranje kamilice i koliko se najviše može investirati u nabavku različitih kombajna za berbu kamilice. Da bi se to proverilo, korišćene su analitičke kalkulacije proizvodnje kamilice, kalkulacije rada poljoprivrednih mašina, kao i dinamičke metode za ocenu investicija (metod prinosne vrednosti).

Utvrđeno je da je ekonomski opravdano preći sa ručnog na mehanizovano ubiranje kamilice na površinama koje prelaze 2,5 odnosno 4 ha kamilice, zavisno od tipa kombajna. Ako se kombajni koriste na površinama manjim od prethodno navedenih, ekonomska efektivnost investicija u njihovu nabavku, odnosno visina njihove prinosne vrednosti, zavisi od tipa kombajna i površine na kojoj se gaji kamilica.

Ključne reči: kamilica, troškovi ubiranja, ručno ubiranje, kombajn, prinosna vrednost.

5 Dr. Sanjin Ivanović, vanredni profesor, Univerzitet u Beogradu, Poljoprivredni fakultet, Odsek za agroekonomiju, Nemanjina 6, 11080 Zemun, Beograd, Republika Srbija, Telefon: +381 112615 315/lok.: 426, E-mail: sanjinivanovic@agrif.bg.ac.rs

6 Dr. Miloš Pajić, docent, Univerzitet u Beogradu, Poljoprivredni fakultet, Institut za poljoprivrednu tehniku, Nemanjina 6, 11080 Zemun, Beograd, Republika Srbija, Telefon: +381 1126 15 315/lok.: 442, E-mail: paja@agrif.bg.ac.rs

7 Dr. Todor Marković, docent, Univerzitet u Novom Sadu, Poljoprivredni fakultet, Departman za ekonomiku poljoprivrede i sociologiju sela, Trg Dositeja Obradovića 8, 21000 Novi Sad, Republika Srbija, Telefon: +381 214853 419, E-mail: todor@polj.uns.ac.rs 